\title{
Son Dönemde Yapılan Değişiklikler Çerçevesinde Belediyelerde Stratejik Planlama Süreci
}

\author{
Strategic Planning Process In Municipalities In The Light Of Recent Amendments
}

\author{
Elif Ayșe ŞAHİN İPEK \\ Dr. $\ddot{O} \breve{g r}$. Üyesi, İzmir Kâtip Çelebi Üniversitesi, \\ IIBF, Maliye Bölümü, elifa.sahin.ipek@ikc.edu.tr \\ https://orcid.org/0000-0003-1256-8325
}

Makale Başvuru Tarihi: 22.08.2019

Makale Kabul Tarihi: 19.09.2019

Makale Türü: Araştırma Makalesi

\section{Çiğdem AKMAN}

Dr. Öğr. Üyesi, Süleyman Demirel Üniversitesi, IIBF, Siyaset Bilimi ve Kamu Yönetimi Bölümü, cigdemakman@sdu.edu.tr https://orcid.org/0000-0002-1936-6884

Anahtar
Kelimeler:
Stratejik
Planlama,
Stratejik Plan
Hazırlama
Rehberi,
Cumhurbaşkanlığl
Hükümet Sistemi,

Strategic Planning,

Guide for Strategic Plan Preparation,,

Presidential Government System,

\section{ÖZET}

Türkiye'de 2003 yılında çıkarılan 5018 sayılı Kamu Mali Yönetimi ve Kontrol Kanunu ile yerel yönetimlerin mali yönetimi yeniden düzenlenmiştir. Belediyelere 5018 sayll Kanun çerçevesinde 2005 yılından itibaren stratejik plan hazırlama zorunluluğu getirilmiştir. 5393 sayılı Belediye Kanununda belediye başkanı stratejik plân ve performans programı hazırlanmasından sorumlu kılınmış ve nüfusu 50.000 üzerinde olan belediyeler için stratejik plan hazırlama zorunluluğu getirilmiştir. Uygulamada stratejik planların hazırlanması, uygulanması ve denetlenmesi aşamasında ciddi sıkıntılar yaşanabilmektedir. En önemli hususlar; stratejik planlama sürecinin koordinasyon ve işbirliği içerisinde yürütülmesi ve etkin denetimidir. Bu anlamda çalışmanın amacı son dönemde yapılan düzenlemeler çerçevesinde meydana gelen değişikliklerin tespit edilmesi ve önerilerde bulunulmasıdır. Çalışma neticesinde Cumhurbaşkanlı̆̆ Hükümet Sistemi ile merkezi yönetim kuruluşlarının stratejik planlama sürecini yürütecek etkin bir kurum oluşturulmasına rağmen yerel yönetim kuruluşlarının etkin bir stratejik planlama süreci yönetebilmeleri için gerekli adımların atılmadığ tespit edilmiştir. Bu çerçevede uygulama süreci dikkatle izlenmeli ve gereken değişiklikler yapılmalıdır.

\begin{abstract}
Turkish Public Financial Management and Auditing Law with $5018^{\text {th }}$ Serial Number enacted in 2003 aimed to reorganize financial management of local governments. The most prominently, municipalities were required to prepare strategic plan after 2005. Furthermore, Municipality Law with $5393^{\text {rd }}$ Serial Number held majors of towns with population over 50 thousands accountable at the first place for preparation of strategic plan and performance program. At the preparation, execution, and auditing phases, serious issues could be encountered. Whereas the most crucial issue is maintenance of strategic planning process within coordination and cooperation and their auditing, the objective of the present study was to determine, assess and draw conclusions about the recent changes that have been occurred within the boundary of legal amendments. Finally, in spite of the new governmental body established by the Presidential Government System to manage strategic planning process of central government departments, it was concluded that the necessary steps have not be taken to manage strategic planning process of local governments efficiently. Accordingly, the implementation process needs to be carefully monitored and necessary steps are required to be taken.
\end{abstract}




\section{GIRISS}

Yerel nitelikteki kamu hizmetlerinin kim tarafından, hangi ölçekte yürütüleceği kamu maliyesinin temel sorunlarından birisi haline gelmiştir. Öncelikle iktisadi, ticari, kültürel ve teknik bazı fonksiyonların yürütülmesi için bazı yerel kaynakların bu iş için ayrılması da mali tevzin kapsamında değerlendirilmelidir. Bu hizmetlerin yürütücüsü merkezi idarenin hiyerarşi yapısı dışındaki kamu tüzel kişilikleridir. Bu kamu tüzel kişilerinin hem finansman hem hizmet bakımından çalışmaya konu olan kısmı, belli bir coğrafi bölgede yaşayan halkın talepleri, kamu hizmet arzı ve bunun finansmanıdır. Burada sunulan hizmetin federal bir niteliği değil, idari vesayete tabi bir statüde sunulması esastır. Sonuçta yerel ihtiyaçlar var, bu yerel ihtiyaçlar bir şekilde karşılanacaktır.

Yerel yönetimler, idari yerinden yönetim birimleridir. Bütün dünyada yaygın bir uygulamadır. Temel amaç merkeziyetçiliğin sakıncalarına karşı, halkın yönetime katılımını sağlamaktır. Yerel ihtiyaçlar ve yerel taleplerle yerel hizmetler arasındaki dengeyi kurarken; verimli ve etkin aynı zamanda ekonomik bir kamu hizmeti sunmaktır. Yeni dönemde bir yerinden yönetim ve yerel hizmet birimi olarak yerel yönetimlerin şeffaflık ve hesap verebilirliği ön plana çıkmıştır. Bunun en önemli iki aracı bulunmaktadır: Stratejik planlar ve faaliyet raporları... Stratejik planlama kullandığı analiz yöntemiyle, şeffaf ve hesap verebilir bir süreci başlatmaktadır. Bu yüzden iyi hazırlanmış bir stratejik planın başarısı kamudaki kaynaklar, hedefler ve performansı dengelemesi ile kendisini gösterecektir.

Yerel yönetimlerin yaşanan değişimi yönetebilmesi, bir başka ifade ile değişime maruz kalan birimler olmamaları için yerel düzeyde stratejik planlamaya önem vermeleri gerekmektedir (Dinçer ve Yılmaz, 2003:66). Aynı zamanda Türkiye'de yerel yönetimlerin artan görev, yetki ve sorumluluklarını daha etkin yerine getirebilmesi ve mali kaynaklarını daha etkin kullanabilmesi için de stratejik planlamaya ihtiyaç bulunmaktadır.

Türkiye'de 2003 yılında yürürlüğe giren 5018 sayılı Kamu Mali Yönetimi ve Kontrol Kanunu ile kamu mali yönetiminde köklü ve önemli değişiklikler yapılarak yerel düzeyde stratejik planlama anlayışı getirilmiştir. Bu doğrultuda 2004 yılında yürürlüğe giren 5216 sayılı Büyükşehir Belediye Kanunu, 2005 yılında yürürlüğe giren 5393 sayılı Belediye Kanunu ve 5302 sayılı İl Özel İdaresi Kanunu'nda bu hususa yer verilmiştir (Akman ve Özaslan, 2018:56). İdarelerin stratejik planlarını hazırlamaları bir yükümlülük olarak tanımlanmıştır. Planların bütçe bağlantısı da şimdilik zayıf olmakla birlikte sürecin bir parçasıdır.

5018 sayılı Kamu Mali Yönetimi ve Kontrol Kanunu ile getirilen en önemli değişikliklerden bir tanesi performansa dayalı mali yapı olmuştur (Öz ve Kaplan, 2005:245). Buna göre Kanunda kamu mali yönetimi; "kamu kaynaklarının tanımlanmış standartlara uygun olarak etkili, ekonomik ve verimli kullanılmasını sağlayacak yasal ve yönetsel sistem ve süreçlerden oluşan bir bütündür" (5018 say. Kanun, md.3), şeklinde ifade edilmiş ve kamu kesimini oluşturan kurumlarda performans yönetimine geçiş gerekli hale gelmiştir. Bir kamu idaresi olan yerel yönetimler de kamu kaynaklarının tutumluluk, etkinlik ve verimlilik kriterlerine göre kullanılmasından ve bu kullanıma esas faaliyetlerini kendilerine yetki verenlere bildirmekten sorumlu tutulmuşlardır. 5018 sayılı Kanun ile yerel yönetimlere getirilen bu yükümlülük, 5302 sayılı İl Özel İdaresi Kanunu, 5393 sayılı Belediye Kanunu ve 5216 sayılı Büyükşehir Belediyesi Kanunu ile de perçinleştirilmiştir.

Yapılan yasal düzenlemelere göre; "il özel idareleri ile nüfusu 50 binin üzerindeki belediyeler kalkınma plan ve programları ve varsa bölge planına uygun olarak stratejik plan ve performans programinı hazırlamakla yükümlüdürler. Stratejik plan ve performans programları bütçelerinin oluşturulmasına esas teşkil eder" (5302 say. Kanun, md.31; 5393 say. Kanun, md.41). Bununla birlikte Türkiye'de 2018 yılı itibariyle fiilen geçilen Cumhurbaşkanlığı Hükümet Sistemi ile pek çok köklü değişiklik yapılmış, stratejik planlama süreci de bu değişikliklerden etkilenmiştir. Literatürde "bütçesiz planlarla" "topal ördek" haline getirilmiş yönetimlerin "plan-hizmet dengesini" sorgulaması açısından da önemlidir. Çalışma bu alanı da kritik başarı faktörü olarak tanımlamaktadır.

13 numaralı Cumhurbaşkanlığı Kararnamesi ile "Strateji ve Bütçe Başkanlığ ”" kurulmuştur. Başkanlığa, kamu kurumlarının stratejik planlarının kalkınma planı, Cumhurbaşkanı tarafından belirlenen politikalar ve orta vadeli programda belirlenen hedef ve amaçlara uygun olarak hazırlanması, uygulaması ve sonuçlarının değerlendirilmesi gibi pek çok önemli görev verilmiştir. Ancak süreçlere ilişkin algoritmalar açık değildir. Yetkili ve sorumluların görev alanları ve süreçleri yönetmesi ile ilgili iş akışları belirsizliğini korumaktadır. Bu çerçevede çalışma yerel yönetimler açısından, stratejik planlamanın belediye faaliyetleri ile olan ilişkisini göstermesi, ve belediyelerde ortaya çıkan sorunların irdelemesi açısından önemlidir. Bu kapsamda belediyelerin stratejik plan hazırlama deneyimlerinin, sorunlu alanları tesbit edilmiştir. Bunun idareye yansıyan mevzuat ve 
koordinasyon tarafı ise stratejik plan hazırlama yönetmeliği ve kılavuzda geçen yönlendirmelerle ele alınmıştır. Sorunlu alanların ortaya konulması süreci engelleyen veya yavaşlatan hatta saptıran unsurlara dikkat çekilmesi bakımından kayda değer bulunmaktadır. Son olarak da belediyelerin stratejik plan hazırlama sürecinin idare tarafını temsil eden ve yeni bir aktör olan Cumhurbaşkanlığı Strateji ve Bütçe Başkanlığı' nın rolüne değinilerek rehber ve yeni aktörlerin görev ve yetki alanı incelenmiştir.

\section{STRATEJIK PLANLAMA VE BELEDIYYLER AÇISINDAN ÖNEMI}

Yerel yönetimlerde; "planlı hizmet sunumu, politika geliştirme, belirlenen politikaları somut iş programlarına ve bütçelere dayandırma ile uygulamayı etkili bir şekilde izleme ve değerlendirmelerini sağlamaya yönelik olarak "stratejik planlama" temel bir araç olarak" uygulanmaktadır. Stratejik planlama; hem kamu mali yönetimine etkinlik sağlayan hem de kurumsal kültür ve kimliğin gelişmesine katkı sağlayan bir süreçtir (DPT, 2006:1). Stratejik plan ise; "kamu kurumlarının orta ve uzun vadeli amaçlarını, temel ilke ve politikalarını, hedef ve önceliklerini, performans ölçütlerini, bunlara ulaşmak için izlenecek yöntemler ile kaynak dağılımlarını içeren planı" ifade etmektedir (5018 say. Kanun, md.3).

Belediyeler, yerelde hizmet üreten ve aynı şehirde yaşayan vatandaşlar için beklentinin yüksek tutulduğu, kamu kurumlarıdır. Vatandaşlar yerelde belediyeleri, öncelikli sorun çözme makamı olarak görmektedir. Bir kısım seçmen tercihleri ile yönetime gelen ekiplerin, hem taahüdü hem de sorumluluğu bu yöndedir. Ancak kamusal hizmet listesi oluşturulurken siyasi parti programından o günkü değişen şartlara, iktidarın üst politika belgelerinden yıllık program ve bütçelere ve elbette önceki dönemin stratejik amaç ve hedeflerinden, buna yönelik örgütlenmelere kadar pekçok şey etkilidir. Buna bir de vatandaş taleplerinin giderek artan seyri eklendiğinde beklentilerin karşılanması düşük, haliyle memnuniyet seviyesi de arzu edilen düzeyde olmamaktadır. Sonuçta bir gayr-1 memnun kitlenin oluşması kaçınılmazdır. Bunun için öncelikler ve önem sıralarının oluşturulması gündeme gelecek ve stratejik planlama da bunun bir aracı olacaktır (Goodman ve Clynch, 2004:23).

Son dönemin yaygın kabulleri kentleşme, demokratikleşme, yerellik anlayışının benimsenmesi üzerine kurgulanmaktadır. Bununla birlikte çevresel duyarlılığın gelişmesi, hizmetlerde halka dönüklük, etkinlik ve hizmette kalitenin arttırılması, saydamlık ve hesap verebilirlik ilkelerinin uygulanması da yerel demokrasinin gelişmesi konusunda önemli birer unsurdur. Bu amaçlara yönelik olarak yerel yönetimler, daha etkin ve yenilikçi yönetim yaklaşımlarını benimsemek durumunda kalmışlardır. Bu çerçevede belirli hedefler gözeten iş listelerinin oluşturulması, şeffaflık açısından önem arzetmektedir. Stratejik planlar nelerin, hangi gerekçelerle, kimler tarafından, hangi zaman aralığında yapılacağını göstermesi açısından önemlidir (Gözlükaya, 2007:124).

Stratejik Planlar ilan edilmesi ile hem idari, hem hukuki, hem de kamuoyu denetimine açık hale gelmektedir. Açıklık ve şeffaflık adına belediyelerin görevleri arasına stratejik planların yapılması ile ilgili maddeler eklenmiştir. Stratejik planlama anlayışı; belediyelerin hizmet önceliklerini, vatandaş ihtiyaç ve taleplerini belirlemesi ve bunları uygulamaya geçirecek kaynağın öngörülmesi ve kaynakların etkin kullanımının sağlaması gibi katkılar sağlaması nedeniyle beklentilerin yüksek tutulduğu birer araç olmuştur (Güngör, 2011:44).

Türkiye'de yerel yönetimlerden hizmet beklentisi giderek artmakla birlikte, yetki ve kaynaklar bir o ölçüde sınırlı kalmaktadır. Hizmetlerin belirlenmesi, belirli bir strateji doğrultusunda iş paketlerinin oluşturulması, tanımlanmış görev, yetki ve sorumluluklar çerçevesinde; istenilen sonuçlara elde etmek bakımından da stratejik plan önemlidir. Çalışmaların verimlilik, etkinlik ve etkililik kriterlerince yürütülmesi, iç ve dış etkenlere uyum konusu, vatandaşların ihtiyaçlarının karşılanması, iletişim, hesap verebilirliğin sağlanması, ve katılımcılı̆̆ın artırılması için de stratejik plan zorunludur. (Dinapoli, 2003:8-9). Yerel yönetimler stratejik plan hazırlayarak amaç ve hedeflerini ve bu amaç ve hedeflere nasıl ulaşılacağını ortaya koymaktadırlar. Bu çerçevede yerel yönetim birimlerinin iç durumunu ve muhtemel gelişmeleri, dış çevre ilişkileri, riskleri, amaç ve hedeflere ulaşma açısından kimin ve hangi araçlarla nasıl kullanılacağı analiz edilmektedir. Böylece stratejik planlama sürecinde, üst yönetimin planlama, faaliyet ve kaynak koordinasyonu faaliyetlerine daha fazla zaman ayırmas1, ihtiyaçların doğru belirlenmesi dolayısıyla da doğru kararların alınması sağlanmaktadır (Özgür, 2004:236).

Özetle, yerel hizmetlerin niteliği ve kurumsal nitelikli stratejik planların ölçek açısından önemi, stratejik planlamayı vazgeçilmez bir yönetim aracı haline getirmektedir. Yerel hizmetlerin görünürlügü ya da tam tersine görünmezliği daha ön plandadır. Merkezi bütçeli kurumların sunduğu hizmetler ile kıyaslandığında belediyeler kısa dönemli çıktı, orta ve uzun dönemli sonuçlar üretebilmekte ve daha ölçülebilir hizmet hedefleri ortaya koyabilmektedir. Bunları stratejik planda belirlemek, hedefleri gerçekleştirecek performans programında tanımlamak, bütçede kaynak tahsis etmek daha kolaydır. Faaliyetlerin maliyetlendirilmesi, belediyelerde daha 
ŞAHIN IPEK, Elif Ayşe ve AKMAN, Çiğdem - Son Dönemde Yapılan Değişiklikler Çerçevesinde Belediyelerde Stratejik Planlama Süreci

kolaydır. Öngörülebilir ve denetlenebilir sonuçlar almak mümkündür. Bu nitelikleri itibariyle stratejik yönetim süreci içinde stratejik plan ve program metinleri, belediyeler için, daha uygulanabilir dokümanlar haline gelmektedir (Y1lmaz ve Erkan, 2014:8-9).

\section{BELEDIYYELERINN STRATEJIK PLAN HAZIRLAMA DENEYIMII: SORUNLU ALANLAR}

Türkiye'nin stratejik planlama tecrübesi öncelikli olarak hukuki düzenlemelerden kaynaklanmaktadır. Mevzuatının iki yılda tamamlandığı ve öncü/pilot kurumlarla sürecin test edildiği, geliştirildiği ve aksamaların gözlendiği bir dönemdir. Özellikle 2003 yılında çıkarılan 5018 sayılı Kamu Mali Yönetimi ve Kontrol Kanunu, idarelerin bu sürece uyumunu da sağlamak açısından zaman da tanımıştır. Ancak eski alışkanlıkların devamı, idari kapasitelerin niteliği, paydaşların çok farklı olması, kaynak sıkıntısı, yeni sistemin bakanlık ve idareler bakımından yeterince içselleştirilemeyişi, tecrübelerin aktarılması ve dinamik bir hafıza oluşumuna mani olmuştur.

2003 yılında çıkarılan 5018 sayılı Kamu Malî Yönetimi ve Kontrol Kanununda yer alan stratejik planlamaya ilişkin hükümler iki sene sonra yürürlüğe girmiş ve idarelerin bu süreci gözlemlemesi ve kendilerini hazırlamaları beklenmiştir. Pilot uygulamalar için Kayseri Büyükşehir Belediyesi ve Denizli İl Özel İdaresi seçilmiştir. İdarelerin öncelikli olarak bu iki şehirin stratejik planlarını, olduğu gibi kopyaladığı görülmüştür.

5216 say1lı Büyükșehir Belediyesi Kanununda büyükşehir belediyesinin görevleri arasında, "büyükşehir belediyesinin stratejik planını hazırlamak", büyükșehir belediye başkanının görevlerinden birisi ise "belediyeyi stratejik plana uygun olarak yönetmek"tir. 5393 sayılı Kanunda da, belediye meclisinin görevleri arasinda "stratejik planı görüşmek ve kabul etmek" yer almaktadır. Belediye encümeninin görevlerinden biri, "stratejik planı inceleyip belediye meclisine görüş bildirmek", belediye başkanının görevlerinden biri ise "belediyeyi stratejik plana uygun olarak yönetmek"tir.

Kanuna göre belediye başkanı, "mahalli idareler genel seçimlerinden itibaren altı ay içinde, kalkinma planı ve programı ile varsa bölge planina uygun olarak stratejik plan ve ilgili olduğu yılbaşından önce de yıllık performans programı hazırlayı belediye meclisine sunmakla" yetkilidir. Stratejik plan, varsa üniversiteler ve meslek odaları ile konuyla ilgili sivil toplum örgütlerinin görüşleri alınarak hazırlanacak ve belediye meclisi tarafindan kabul edildikten sonra yürürlüğe girecektir. Nüfusu 50.000'in altında olan belediyelerde stratejik plan hazırlama zorunluluğu bulunmamaktadır. Ayrıca belediye bütçesinin plan-bütçe ilişkisi bakımından, "belediyenin stratejik plânına ve performans programına uygun" olarak hazırlanmas1 gerekmektedir (DPT, 2006:1-2; 5216 say. Kanun, md.7,18; 5393 say. Kanun, md.18,34,38,41,61). Süreç, kanuni bir yükümlülük olarak görülmüş, prosedürler yerine getirilmeye çalış1lmıştır.

Kalkınma Bakanlığı tarafindan 2006 yılında “Kamu İdarelerinde Stratejik Planlamaya İlişkin Usul ve Esaslar Hakkında Yönetmelik" hazırlanarak yerel yönetimler de dâhil olmak üzere kamu kuruluşlarına stratejik planlama sürecinde yol gösterilmesi amaçlanmıştır. Bu yönetmelik ile kamu kurum, kuruluş ve idarelerinin stratejik planlama yapmaları gereken tarihler listeler halinde gösterilmiştir. Bu tarihlerin saptanmasında "Stratejik Yönetim Araştırması" sonuçlarından faydalanılmıştır. Belirlenen takvimde stratejik planlama sorumluluğuna sahip bütün kamu kuruluşlarının 2010 yılında stratejik plan uygulamasına geçmeleri hukuken bir yükümlülük olarak belirtilmiştir (Şahin İpek, 2014:346). Stratejik planlama süreci devam ederken mevzuatlar yetiştirilmeye çalışılmış, sonraki dönemde DPT'nin kapatılıp Kalkınma Bakanlığına dönüşmesi idareleri muhatapsız bırakmıştır. Son dönemde 15 Temmuz menfur darbe girişimine karışan stratejik planlamada görevli personeller arasında yaşanan ihraçlar; Cumhurbaşkanlığı Hükümet Sistemi ile getirilen yeni idari yapının organizasyonundaki gecikmeler, kurumların idari kapasitesindeki azalma ve muhatap bulma konusundaki aksamalar stratejik yönetim sürecini yavaşlatmıştır.

Yerel yönetim birimlerine ilişkin takvim ve süreç kendi kanunlarında ayrıca yer almaktadır. İlk başlarda nüfusu 50.000 'in üzerinde olan belediyelerin stratejik planlarını hazırlamaları için 5393 sayılı Belediye Kanunun yürürlüğe girdiği 13 Temmuz 2005 tarihinden itibaren bir yıl süre verilmiş, bu çerçevede 205 belediyenin stratejik planlarını 13 Temmuz 2006 tarihine kadar hazırlayarak meclislerinden onay almaları istenmiştir (Songür, 2008:71). Yine yerel yönetimler ile ilgili düzenlemede, stratejik planın hazırlanmasından sonra gerçekleştirebilmesi için ilgili yılbaşından önce performans programı hazırlamaları gerektiği belirtilmiştir. Anlaşılacağı üzere, yerel yönetim birimleri 2007 yılında performans programlarını gerçekleştirmek ve bundan dolayı tekrar 2007 yılından önce performans programlarını hazırlamak zorunda kalmışlardır. Bu süreçte mahalli idarelerin kendilerine rehberlik edinebilecekleri belgeler yalnızca DPT Müsteşarlığı tarafından hazırlanan "Stratejik Plan Hazırlama Rehberi" ve Maliye Bakanlığınca 2004 yılında pilot kurumlar için hazırlanan 
"Performans Esasl Bütçeleme Rehberi"dir. Mevcut durum yapılması planlanan faaliyetlere uygun bütçe hazırlanması ile ilgili dönüşümün yapılması yerine, prosedürel bir zorunluluğu karş1lamak üzere bütçeye uygun plan ve programların oluşturulmasını ve yerelde öğrenme sürecinin uzamasına sebep olmuştur. Ayrıca, performans esaslı bütçeleme sistemi uygulamasına kuşkuyla bakılmasına sebep olmuştur (Şahin İpek, 2014:347). Uygulama incelendiğinde ise, yerel yönetim birimlerinin hazırlayacakları stratejik planların hazırlanması konusunda bazı yerel idarelerin, Kalkınma Bakanlı̆̆ı sorumluluk alanına girmemekle birlikte, yoğun bir şekilde bakanlıktan bilgi ve yardım talebinde bulunduğu, diğer yerel idarelerin ise stratejik planlarını danışmanlık firmalarına yaptırdığı gözlenmiştir (Kalkınma Bakanlığı, 2006:60-61). İlgili yönetmelikte geçen "danışmanlık hizmeti" uygulaması, idarelerce amaçlanan şekilde kullanılmamıştır. "Bul-değiştir" tarzında planlar ortaya çıkmış bu da idarelerin bir planı olduğu hissini ortadan kaldırmıştır. Planlar sahiplenilmemiştir.

Yerel yönetim reformu ile ilgili geçiş aşamasının kısa olduğu göz önüne alındığında, yerel yönetim birimleri ilgili yükümlülükleri olan merkezi idarelerin beşeri ve idari kapasiteleri geliştirme, reforma ayak uydurma ve liderlik etme hususunda geri kaldıkları ortaya çıkmaktadır. Bilindiği gibi İçişleri Bakanlığına mahalli idarelerin stratejik plan çalışmalarını koordine etme ve mahalli idarelerden elde edilen faaliyet raporları aracılığıyla "Mahalli İdareler Genel Faaliyet Raporu" hazırlama hazırlanması sorumluluğu verilmiştir. Ayrıca, kurum içi/kurumlar arası etkileşimi güçlendirme ve tecrübe ve bilgi aktarımını sağlayacak mekanizmaların İçişleri Bakanlığı tarafından oluşturulması gerekmiştir. İdari kapasitelerin stratejik yönetime uyumlu olmadığ 1 kurumlarda ya yasal zorunluluktan kaynaklanan bir yasak savma ya da ciddi miktarda kaynakların dış danışmanlık şirketlerine aktarılmasına sebep olan durumlar ortaya çıkmıştır. İdari kapasitede beklenen iyileşme sağlanamamıştır.

Türkiye'de üst ölçekli plan niteliğini taşıyan başlıca belgeler; sektörel planlar, bölgesel planlar ve kalkınma planlarıdır. Ancak bu planlar ile yerel stratejik planlar arasında ne şekilde bir bağlantı kurulması gerektiği konusunda sıkıntılar ortaya çıkmıştır (Şahin İpek, 2013:265). Benzer bir duruma farklı ülke deneyimlerinde de rastlanmış, üst politika belgelerinin sayıca fazla olmasının bütçelere yansıtılmasında yaşanan çeşitli sorunların çözümü, referans metinlerin sadeleştirilmesi ve genel ilkelerin belirlenmesi olarak görülmüştür (Hou ve Ma, 2006:144).

Yerel yönetimler siyaseten ve yerel halk tarafından seçildiği için, öncelikler yerel nitelikli olmakta, siyasi partilerin parti programına yansıyan hususlar gündeme alınmak istenmektedir. Buna bir de ilgili belediye başkanının yönetim becerilerinin sınırları sorunu eklendiğinde stratejik planlar, ulusal ölçekli planlar arasındaki denge şaşmaktadır. Bölgesel ölçekli planlar ile yerel planlar arasında bir koordinasyon sağlanmış ancak makro planlara yeterli yakınsama görülmemiştir (Akdoğan, 2007:53-58). Bu gelişmelere göre plan kademelenmesinde çoğunlukla bölgesel gelişim planı ile il gelişim planı arasında bir bağın kurulması gerekmektedir. Bu çerçevede plan amaçlarının birbiriyle uyumlu olması ve gelişim planları ile kurumsal planlar arasında aynı biçimde amaçlar açısından bir uyumun olması önemlidir (Haşar, 2008:301-302). Benzer biçimde il genelinde hazırlanan planlar (il özel stratejik planı, büyükşehir belediyesi stratejik planı, ilçe belediyeleri stratejik planı) arasında uyum bulunmaması, plan amaçları ile arasında uyumsuzluğa ve uygulamaların birbirini nötralize etmesine neden olacaktır.

Burada bahsedilen uyum ile hiyerarşik bir uyum anlamına gelmemektedir. Burada sözü edilen planlar arasında eşgüdümün gerçekleşmesidir. Planlar arasındaki uyum koordinasyon ve kaynakların verimli ve etkin kullanılması açısından önemlidir (The World Bank, 1998:9). Eşgüdümün sağlanabilmesi için bazı yerel idarelerde bireysel çabalara girilmiş olsa da yasal bir altyapıya ihtiyaç bulunmaktadır. Bu nedenle yasal bir düzenleme ile il ölçeğinde planlama koordinasyon birliği kurulacağı hüküm altına alınabileceği gibi il ölçeğinde yönetim birimleri arasında plan önceliklerinin belirlenmesi aşamasında işbirliğine ilişkin manifesto imzalanması yönetişim çabası konusunda samimiyetin gösterilmesi bakımından önemlidir (Şahin İpek, 2013:265).

Stratejik planların uygulanması ile ilgili getirilen üç yıllık süre ve idarecinin değişmesi, yerel seçimlerin yapılması gibi sebeplerden dolayı stratejik planlarda yenilenme mecburiyeti doğmaktadır. Altı ay içinde meclislerinden onay alınacak stratejik planlar bir zaman kısıtının başlangıcıdır. Yönetimin değişmesi ile gelen yeni kadrolar, yeni vizyon ve öğrenme maliyeti anlamına gelmektedir. $\mathrm{Bu}$ da bir zaman maliyeti olarak süreçlere yansımaktadır. Dolayısı ile plansız bütçeler, bütçesiz planlar oluşmaktadır (Acar ve Şahin, 2009:86). $\mathrm{Bu}$ da kurumsal hizmet karması ve kamusal faydayı doğrudan etkileyen durumlardır. 


\section{SON DÖNEMDE YAPILAN DEĞİŞIKLIKKLER ÇERÇEVESINDE BELEDIYYELERDE STRATEJIKK PLANLAMA SÜRECI}

Türkiye'de 5018 sayılı Kamu Mali Yönetimi ve Kontrol Kanununun kabul edilmesi ve ardından 2003 y1lında Kamu İdareleri İçin Stratejik Plan Hazırlama Kılavuzu hazırlanması belediyelerde stratejik planlama sürecini başlatan gelişmelerdir. İlk olarak 2003 yılında hazırlanan bu kılavuz, 2006 ve 2018 yıllarında güncellenmiştir. 2018 yılında hazırlanan rehber pek çok önemli değişikliği beraberinde getirmiştir.

2018 yılı itibariyle ise, parlamenter sistemden “Cumhurbaşkanlığı Hükümet Sistemi”ne geçilmiştir. Stratejik planlama süreci devam etmekte, sadece kurumların muhatapları açısından bir farklılaşma sözkonusu olmaktadır. Oldukça köklü bir değişimi de beraberinde getiren bu yeni dönem, uzun yıllardır devam eden hükümet sistemi tartışmalarının bir sonucu olarak karşımıza çıkmaktadır. Yeni sistemde, etkin koordinasyon sağlayan, hızlı karar alabilen ve yalın bir yapı oluşturulması amaçlandığı söylenebilir. Bu çerçevede bürokrasinin zayıflatılması adına yönetim kademelerinin azaltılması, görev tanımlarının açık şekilde yapılması ve yetki karmaşıklığının giderilmesi şeklinde adımlar atılmıştır (Akman Ç., 2019:659-675).

Cumhurbaşkanlığı Hükümet Sistemi; "Doğrudan halk tarafindan seçilen ve tüm yürütme görev ve yetkisine sahip olan Cumhurbaşkanının bulunduğu, millet adına yetki kullanan kuvvetlerin sert ayrilı̆̆ına dayanan yönetim sistemidir" (TBMM, 2018:16-18). Cumhurbaşkanlığı Hükümet Sistemine geçişin gerektirdiği yeniden yapılandırmaya ilişkin yasal düzenlemelerin bir kısmı önce 16 Nisan 2017 Anayasa değişikliği ile daha sonra da Bakanlar Kurulunun 703 sayılı KHK ve Cumhurbaşkanlığı Kararnameleri ile düzenlenmiştir. 2017 yılında 6771 sayılı Kanunla yapılan Anayasa değişikliği ile; "Cumhurbaşkanlığı ihdas edilmiş, Bakanların Cumhurbaşkanı tarafindan TBMM dışından atanması usulü getirilmiş, Cumhurbaşkanlı̆̆g Genel Sekreterliği kurumu kaldırılmıştır" (Turan, 2018:60).

Yeni yönetim sistemine ilişkin temel değişikler 10.07.2018 tarih ve 30474 sayılı Resmi Gazetede yayımlanan "1 numaralı Cumhurbaşkanlığı Teşkilatı Hakkında Cumhurbaşkanlığı Kararnamesi" ile yapılmıştır. Yeni yönetim sisteminde yürütme ve yasama tamamen ayrılmaktadır. Cumhurbaşkanı, Cumhurbaşkanı yardımcılarını ve bakanları atama ve yürütme yetkisi ile ilgili hususlarda Cumhurbaşkanlığı kararnamesi çıkarabilme yetkisine sahiptir. Buna karşılık Cumhurbaşkanının sorumsuzluğu kaldırılarak, belli şartlarla cezai sorumluluğu getirilmiştir (TBMM, 2018:16-18). Görüldüğü üzere Başbakanlık makamı kaldırılmış, Cumhurbaşkanlığı yardımcılığı getirilmiş ve Cumhurbaşkanı yardımcıları ve bakanlar doğrudan Cumhurbaşkanı tarafından atanmaktadır. Halk tarafından seçilen Cumhurbaşkanı aynı zamanda 100.000 seçmen tarafından aday da gösterilebilecektir. Bakanlık sayısı 26'dan 16'ya düşürülmüş, milletvekili sayıs1 550'den 600'e çıkarılmıştır. Aynı zamanda milletvekili seçilme yaşı 18 olmuştur. Yeni yönetim sisteminde Cumhurbaşkanı ise; halka karşı sorumluluğu olan, yetkisi çerçevesinde Cumhurbaşkanlığı Kararnamesi çıkarabilen, nitelikli veto yetkisi bulunan ve halk tarafından 5 yılda bir seçilen hem hükümetin, hem de devletin başı olan kişidir. Stratejik planlama süreci açısından bakıldığında ise koordine edici idareler başta olmak üzere, bazı değişiklikler yapıldığı görülmektedir. Bu doğrultuda çalışmanın bundan sonraki kısmında koordine edici idarelerde ve stratejik plan hazırlama yönetmeliği ve kılavuzunda değişim ele alınmıştır.

\subsection{Stratejik Plan Hazırlama Yönetmeliği ve Kılavuzunda Değişim}

İlk sürümü 2003 yılında hazırlanan Kamu İdareleri İçin Stratejik Plan Hazırlama Kılavuzu, 26.05.2006 tarihli Resmi Gazetede yürürlüğe yayımlanan Kamu İdarelerinde Stratejik Planlamaya İlişkin Usul ve Esaslar Hakkında Yönetmelik çerçevesinde güncellenmiş ve 2006 yılında ikinci sürümü yayınlanmıştır. Yönetmeliğin 2018 yılında yenilenmesinin ardından aynı yılda Kamu İdareleri İçin Stratejik Plan Hazırlama Kılavuzunun üçüncü sürümü yayınlanmıştır. Bununla birlikte, önceki yıllardan farklı olarak, ilk defa 2018 yılında Belediyeler İçin Stratejik Plan Hazırlama Kılavuzu ile Stratejik Planlama İçin Analiz ve Yöntemler Rehberi yayınlanmıştır. Son dönemde hazırlanan bu kılavuz rehberler, belediyelerde stratejik planlamanın sistematiği ve içeriğine ilişkin önemli değişiklikleri beraberinde getirmiştir. Bu değişiklikler;

- Stratejik planlama sürecinin organizasyonuna ilişkin değişiklikler,

- Stratejik planlama sürecinde durum analizine ilişkin değişiklikler,

- Amaç, hedef ve göstergelerin belirlenmesine ilişkin değişiklikler olmak üzere üç başlıkta ele alınmıştır. 


\subsubsection{Stratejik Planlama Sürecinin Organizasyonuna İlişkin Değişiklikler}

2006 y1lı Kılavuzunda stratejik planın hazırlanmasına ilişkin koordinatör birim olarak strateji geliştirme birimleri ve stratejik planlama ekibine yer verilmiştir. Üst yöneticiye ise stratejik plan çalışmalarının başladığını duyurma ve misyon, vizyon ve temel ilkelerin belirlenmesinde daha aktif bir rol verilirken ihtiyaç duyulduğu hallerde stratejik plan çalışmalarına katılacağı öngörülmüştür. Belediyeler için hazırlanan 2018 yılı kılavuzunda ise önceki kılavuzdan farklı olarak "Strateji Geliştirme Kuruluna” yer verilmiştir.

Strateji Geliştirme Kurulu; büyükşehir belediyelerinde; genel sekreter ve yardımcıları ile Başkanın uygun göreceği yönetici ve diğer kişilerden; diğer belediyelerde ise başkan yardımcıları ile başkanın uygun göreceği yönetici ve diğer kişilerden oluşturulacaktır. Kurul başkanı, belediye başkanı olacaktır. Kurula; alternatif misyon, vizyon ve temel değerler taslakları ile taslak amaçlar ve hedef kartlarının değerlendirilerek nihai hale getirilmesi görevi verilmiştir. Kılavuzda strateji geliştirme birimlerinin plan hazırlıklarını koordine edici rolü devam ettirilmekte; üst yöneticiye Strateji Geliştirme Kurulu Başkanı sıfatı ile daha aktif bir rol verilmektedir. Stratejik Planlama Ekibinin harcama yetkilileri temsilcileri, strateji geliştirme birimi yöneticisinin oluşturacağ1 ekibe genel sekreter ya da bir başkan yardımcısının başkanlık edeceğinin altı çizilmiştir. Kılavuzda ayrıca harcama birimlerinin, aktif katılımının önemi vurgulanmıştır. Buna göre denilebilir ki yeni yönetim sistemi ile kurumsal stratejilerin oluşturulması ve uygulanmasında, katılımcılığın arttırılması ve planın sahiplenilmesi için biçimsel önlemler alınmıştır ve üst düzey yöneticilerin aktif katılımı istenmektedir. Kılavuzun bu yaklaşımı operasyonel faaliyetler ile üst düzey stratejiler arasında uyum sağlanmasına, planın her kademede anlaşılması ve sahiplenilmesine imkân vermektedir.

\subsubsection{Stratejik Planlama Sürecinde Durum Analizine İlişsin Değişiklikler}

2006 yılı Kılavuzunda durum analizi kapsamında gerçekleştirilmesi beklenen çalışmalar; “i) tarihsel gelişim, ii) kuruluşun yasal yükümlülükleri ve mevzuat analizi, iii) kuruluşun faaliyet alanları ile ürün ve hizmetlerinin belirlenmesi, iv) paydaş analizi, v) kuruluş içi analiz, vi) çevre analizi" şeklinde sıralanmıştır (DPT, 2006:1526). Ancak bu yaklaşım, idarelerin aynı zamanda stratejik planlamayı öğrenme sürecinde bulunmaları ve çoğu idare için beklenen analizlerin yapılmasını sağlayacak sağlıklı verilerin bulunmaması sebebiyle, özellikle belediyelerin stratejik planlarında analiz kısımlarının birbirleriyle büyük oranda benzerlik göstermelerine, plan kapsamının bu alana daha fazla yer ayırmasına, burada sunulan bilgilerin analitik bir analiz yapılmadan salt niceliksel verilerin paylaşılması şeklinde anlaşılmasına yol açmışır. Ancak yeni kılavuzda durum analizi kapsamında yapılması beklenen çalışmaların detaylı olarak belediye özelinde gerçekleştirilmesine ancak planın nihai halinde saptanan mevcut durumun plan amaç ve hedeflerini ne şekilde etkilediğine ilişkin öz bilgileri içerecek şekilde sunulmasına önem verilmiştir. Bununla birlikte durum analizi kısmının daha analitik bir şekilde ele alındığı, belediyelerin kendi öznel durumlarını aktarabilmelerine imkân verildiği, durum analizi kapsamında sunulan bilgilerin niceliksel veriler yanı sıra niteliksel değerlendirmelerle zenginleştirilmesi gereğinin altı çizildiği söylenebilir.

Buna göre yeni kılavuzda durum analizi kapsamında belediyelerin yapmaları gereken çalışmalar; “i) kurumsal tarihçe, ii) uygulanmakta olan stratejik planın değerlendirilmesi, iii) mevzuat analizi, iv) üst politika belgeleri analizi, v) faaliyet alanlart ile ürün ve hizmetlerin belirlenmesi, vi) paydaş analizi, vii) kuruluş içi analiz, viii) PESTLE analizi, ix) GZFT analizi, x) tespitler ve ihtiyaçların belirlenmesi” aşamalarından oluşmaktadır (KB, 2018:12-29). Bu bakımdan yeni kılavuz durum analizi kapsamında yeni analiz alanlarını ortaya koymuş, bununla birlikte önceki yıllarda yapılan analizlere de daha analitik bir yaklaşım getirerek, plan amaç ve hedeflerinin belirlenmesinde, belediyelerin daha gerçekçi bir yaklaşımla davranmaları gereğini ortaya çıkarmıştır. Bu bakımdan belediyelerin yeni plan döneminde risk yönetimi ve kurumsal yönetim konularına daha fazla yoğunlaşmaları, bu yönetim yaklaşımlarını kendi yapılarına adapte etmeleri önem arz etmektedir.

Kurumsal Tarihçenin Değerlendirilmesi: Belediyelerden, önemli yapısal değişimlerin belediyenin yeni plan dönemini nasıl etkilediğini değerlendirmesi istenmektedir. Dolayısıyla belediyelerden uzun uzadıya salt tarihsel gelişim bilgisi vermeleri yerine, bu gelişimden çıkarımlarını ortaya koymaları beklenmektedir.

Uygulanmakta Olan Stratejik Planların Değerlendirilmesi: Önemli bir yeniliktir. Bu değerlendirmede, belediyelerin bu değerlendirme ile geçmiş dönem planında yer verilen amaç, hedef ve performans göstergelerinin "ilgililik analizi” ile "etkililik, etkinlik ve sürdürülebilirliğini” analiz etmeleri istenmektedir. Gelecek plan dönemleri için değerlendirmenin, belirli süreler içerisinde yapılan sürekli izlemelere dayandırılması istenmektedir ve iç denetim birimi ile sıkı bir işbirliğini gerektirmektedir. 
Nitekim bu husus klavuzda da vurgulanmıştır. Buna göre stratejik plan değerlendirme raporunun nihai hale getirilmesinde iç denetim ile Sayıştay performans denetimi bulgularından faydalanılmalıdır. $\mathrm{Bu}$ hususun altı çizilerek, yeni dönemde, iç denetim birimlerinden belediye içinde daha aktif olarak faydalanılması gerektiği, Sayıştay performans denetim raporlarının belediye meclisinde görüşülmesinde, stratejik plan değerlendirme raporunun belediye faaliyet raporlarına esas teşkil etmesi dolayısıyla, daha analitik bir bakış açısını gerektirdiği ortaya çıkmaktadır.

Illgililik Analizi: İç ve dış çevre koşullarındaki değişimlerin gözlemlenmesi, tespit ve ihtiyaçlarda bir değişikliğe yol açıp açmadığı, eğer bir değişiklik gerektiriyorsa hedef ve performans göstergelerinde bir değişiklik yapılıp yapılmayacağının değerlendirilmesi ile ilgilidir. Bu yaklaşım stratejik planları durağan ve mekanik bir yapıdan kurtararak, ilgili olduğu dönemin ihtiyaçlarına cevap verecek dinamik bir yapıya kavuşturulmasında önemli bir adımdır. Bunun için;

- Etkililik değerlendirmesi ile performans hedeflerine ulaşılması yoluyla stratejik amaçlara ulaşılıp ulaşılmadığının değerlendirilmesi ve bu gerçekleşmelerin kalkınma planına katkısının ne düzeyde olduğunun değerlendirilmesine ilişkindir. Bu yaklaşım, uzun yıllarca çaba gösterilen ancak bir türlü ulaşılamayan politika - plan - bütçe ilişkisinin kurulabilmesi için önemli bir adımdır. Buna göre planın bütünselliğinin diğer bir deyişle gösterge - hedef - amaç uyumunun yanı sıra idare düzeyinde stratejik plan yapılmasını gerektiren asıl sebep olarak planın üst politikalara uyumunun ciddiyetle değerlendirilmesi istenmektedir.

- Etkinlik değerlendirmesi ile plan amaçlarına ulaşılmasında maliyet yapısının değerlendirilmesi istenmektedir. Bu yaklaşım mali disipline verilen önemi göstermektedir.

- Sürdürülebilirlik değerlendirmesi ile plan hedeflerini etkileyen "risklerin değerlendirilmesi" ve bu değerlendirmeler sonucunda önlemler alınması istenmektedir. Bu yaklaşım risk yönetiminin yeni dönemde öneminin artacağını göstermektedir.

Mevzuat Analizi: İdareler yönetim alanları ile ilgili pek çok mevzuat geliştirebilmektedir. Bunlar bazen zaman içinde tekrarlanmakta, bir önceki dönem ya da daha önceki yıllarda yapılan bir düzenleme ile çelişebilmektedir. Belediyelerden sadece yasal yükümlülüklerinin gerektirdiği hizmetleri değil, hizmet sunumunda özel sektör, diğer idareler ve sivil toplum kuruluşları ile ilişkilerini analiz etmelerinin yanı sıra, mevzuat değişikliği gerektiren durumlara ilişkin tespitleri de oluşturmaları beklenmektedir. $\mathrm{Bu}$ yaklaşım fark1, yeni dönemde, belediyelerin hizmet sunumunda maliyet - etkinliğin önündeki mevzuat kaynaklı engellerin analiz edilmesini gerektirmesi sebebiyle anlamlıdır ve umut vericidir.

Üst Politika Belgelerinin Analizi: Birim sratejik planları, idare stratejik planları ve ülke stratejik planları bir bütünü tamamlayan makro planlama unsurlarıdır. Dolayısıyla yapılan analizler, çoğu durumda, politika - plan - bütçe ilişkisinin sağlanmasında, belediyelerce zorlama hedef ve amaçlar belirlenmesinin önünü kesecek ve belediyelere kalkınma planı ile kendi planları arasında ilişki kurulmasını zorunlu hale getirecektir. $\mathrm{Bu}$ analiz ile kalkınma planında doğrudan yer verilen roller değil; belediyenin mevcut işlevleri ile katkı verebileceği alanların ortaya çıkartılması istenmektedir. Bu çalışmanın samimiyetle yapılması, stratejik plan uygulamasının ve plan hedeflerine ulaşılmasının, kalkınma planına ne ölçüde katkısının olduğunun görülmesini de kolaylaştıracaktır (Acar ve Şahin, 2009:88).

Faaliyet Alanları ile Ürün ve Hizmetlerin Belirlenmesi: Mevzuat analizinin çıktılarından yararlanılarak belediyenin sunduğu temel hizmetlerin belirlenmesi suretiyle bu temel hizmetlerin belirli faaliyet alanları altında toplulaştırılmasına dayanır.

Paydaş Analizi: iç paydaşlar ile dış paydaşların öneri ve beklentilerinin stratejik plana yansıtılması amaciyla yapılır.

- Kurum Íçi Analiz, önceki kılavuzda da yer bulan bir analiz olmakla birlikte yeni kılavuzda bu analizin belediye iş süreçlerinin analizi yapılarak insan kaynaklarının yetkinlik düzeyi, kurum kültürü, teknolojik ve bilişim alt yapısı, fiziki kaynakların analizi, mali kaynakların analizinin gerçekleştirilmesine dayandırılmıştır. Buna göre belediyelerden yeni dönemde, kurumsal yönetim ve performans yönetimi gibi yeni yönetim tekniklerinden daha fazla faydalanması beklenmektedir. $\mathrm{Bu}$ analizlerde niceliksel verilerin niteliksel analizlerle desteklenmesi özellikle önem arz etmektedir.

- PESTLE Analizi, yeni bir analiz yöntemidir. Bu analiz ile belediye diş çevresinin politik, ekonomik, sosyokültürel, teknolojik, yasal ve çevresel faktörler açıldan değerlendirilmesi 
istenmektedir. Bu analiz belediyelerde risk yönetim tekniklerinin içselleştirilmesine imkân verecek niteliktedir.

GZFT Analizi, belediyenin kendisini güçlü-zayıf yönler, firsatlar-tehditler açısından değerlendirdiği, önceki kılavuz döneminde de uygulanan analiz yöntemidir. Belediyenin güçlü ve zayıf yönleri kuruluş içi analiz ile durum analizi kapsamında yapılan diğer çalışmalar neticesinde tespit edilir. Firsatlar ve tehditler ise PESTLE analizi sonuçları neticesinde belirlenir.

Rehbere göre durum analizi sonucunda yapılan tespitler ve bu tespitlere dayanarak ihtiyaçların belirlenmesi aşamasına geçilecektir. İhtiyaçlar, amaç ve hedeflerin dayanak noktasını oluşturur. Yapılacak olan bu çalışmalar, belediyelerin stratejik planlarını doğru bir şekilde hazırlamalarına ve uygulamalarına katkı sağlayacakları için oldukça etkili olması beklenmektedir.

\subsubsection{Amaç Hedef ve Göstergelerin Belirlenmesine İlişkin Değişiklikler}

Belediye başkanının misyon ve vizyon bildirimi için perspektif vermesinin ardından, stratejik planlama ekibi katkılarıyla alternatif çalışmalar hazırlanır ve taslaklar Strateji Geliştirme Kuruluna sunulur. Kurul bu taslaklardan yararlanarak misyon, vizyon ve temel değerlerin son halini belirleyerek genel çerçeveyi oluşturur. Sonrasında 2018 yılı rehberine göre amaçlar, harcama birimleri ile işbirliği kapsamında stratejik planlama ekibi ortaya koyacaktır. Amaç sayısının belediye ana faaliyet alanlarını geçmeyecek şekilde, en fazla on ve bu amaçlardan bir tanesinin kurumsal kapasitenin artırılması ile ilgili olması gerektiği belirtilmiştir.

Taslak amaç ve hedeflere ilişkin faaliyetler, stratejik planlama ekibinin koordinasyonunda, harcama birimleri ile birlikte yapılmalıdır. Bu faaliyetler kapsamında, harcama birimlerince sorumlu oldukları her bir hedef için hedef kartları oluşturulacak, strateji geliştirme birimi tarafından konsolide edilen hedef kartları Strateji Geliştirme Kurulunca nihai hale getirilecektir. Hedef kartlarında; her bir amaç için belirlenmiş hedef, plan başlangıç değerleri, hedefe etkisi, izleme ve raporlama sıklığını kapsayacak şekilde performans göstergeleri, sorumlu birim ile işbirliği yapılarak oluşturulacaktır. Birim veya birimlerin, riskleri, faaliyet ve projeleri, maliyet tahmini, hedefin oluşturulmasına neden olan tespitleri ile ihtiyaçlarına yer verilecek, riskler analiz edilecek ve izlenecektir.

- Risklerin tespit edilerek analiz edilmesi ve bu risklere ilişkin önlemlerin belirlenmesi gereklidir. Risk değerlendirmesi sonucunda; hedef, performans göstergesi, gösterge değerleri, göstergelerin hedefe etkisi, faaliyet ve projeler ile maliyette değişiklikler yapılabilecektir. Böyle bir değişikliğin yapılmasına karar verilmesi durumunda stratejik plan güncelleme prosedürleri devreye girecektir. Rehbere göre güncelleme, bir stratejik plan döneminde "en fazla iki kere" gerçekleştirilebilir. Güncelleme ile ilgili faaliyetler strateji geliştirme biriminin koordinasyonunda sorumlu ve ilgili birimlerin katılması ile yapılır. Gerçekleştirilen güncelleme belediye meclisinin onayı ve plana son hali verildikten sonra Strateji ve Bütçe Başkanlığına iletilecektir.

- Etkin izleme ve değerleme sürecin yönetilmesi bakımından önem taşımaktadır. İhtiyaç duyulan güncellemelerin yapılabilmesi, risk değerlendirme sonuçlarının bu bakımdan bir anlam kazanabilmesi için belediyelerde etkin bir "izleme ve değerlendirme" sisteminin kurulması gereklidir. Rehberde izleme ve değerlendirme sisteminde üretilen bilgilerin raporlar ile kaydedilmesi gerektiğinin altı çizilmiştir. Rehber 2006 yılı k1lavuzundan farklı olarak, raporlamanın taşıması gereken özellikleri ve değerlendirme kriterlerine açıkça yer vermiştir. Bununla birlikte bu özellik ve değerlendirme kriterlerini, izleme ve değerlendirme sisteminin kilit unsuru olarak ele almıştır.

Rehberde izleme ve değerlendirme sürecinde, altı aylık dönemlerde izleme toplantıları, bir yıllık dönemde ise değerlendirme toplantısı yapılması konusu belediyelerin tercihine bırakılmıştır. Söz konusu toplantılara belediye başkanı başkanlığında, genel sekreter veya yardımcıları, başkan yardımcıları, strateji geliştirme birim yöneticisi ile Başkanın uygun göreceği yönetici ve diğer kişilerin katılımı ile gerçekleştirilmesi gereklidir. Bu toplantıların yapılması durumunda belediye başkanı ayrıca, stratejik planın kalan süresi için hedeflere nasıl ulaşılacağı ile ilgili ihtitaç duyulan tedbirleri belirler ve ilgili birimleri görevlendirilir. Rehberde tercihe bırakılan bir yöntem olmakla birlikte, söz konusu toplantıların ciddiyetle gerçekleştirilmesi 5018 sayılı Kanunla üst yönetime verilen sorumlulukların yerine getirilmesi açısından önem arz etmektedir.

Rehberin en önemli özelliklerinden birisi amaç - hedef - performans göstergesi ilişkisinin kurulmasında konuya risk esaslı yaklaşması, risk değerlendirme ve yönetimini sürecin temeli haline getirmesidir. Bu husus esasen 2016 kılavuzun da zımni olarak ele alınmıştır. Buna göre kılavuzda amaç ve hedeflerin belirlenmesinden sonra stratejilerin belirlenmesine yer verilmiştir. Bu kısımda stratejiler, "kuruluşun amaç ve hedeflerine nasıl ulaşılacağını gösteren kararlar bütünü", şeklinde tanımlanmış idi. Stratejilerin belirlenmesinde ise "kritik 
sorular yöntemi" ya da "GZFT analizi" sonuçlarından yararlanılabileceği ifade edilmişti. Ancak uygulamada, stratejiler, olası riskleri göz önüne almadan faaliyet ve projelere benzer şekilde ifade bulmuş, dolayısıyla stratejik planları statik yapıdan kurtarmaya yeterli olmamıştı. Bu bakımdan 2018 yılı rehberinin risk değerlendirme yöntemini sürecin temeli haline getirmesi anlamlıdır. Bununla birlikte rehberin bu yaklaşımı, belediyelerde iç kontrol sistemine ilişkin çalışmalarla stratejik plan çalışmalarının eşgüdümlü, birbirini destekler nitelikte ilerlemesine yardımcı olacak türdendir. Bununla birlikte rehberde getirilen önemli bir değişiklik; her bir hedefe ulaşılmasından sorumlu birimlerden işbirliği yapılacak birimlere kadar tespitlerin yapılması aşamasıdır. $\mathrm{Bu}$ suretle izleme ve değerlendirme aşamalarında da sorunlu alanların neler olduğunun, birim bazında tespit edilebilmesi ve bu çerçevede birim bazında iyileştirme alanlarının ortaya çıkarılmasına temel oluşturmasıdır. 2006 yılı kılavuzunda bu durum eylem planları aracılığıyla sağlanmaya çalışılıışıtı. Buna göre eylem planında, amaç, hedef ve faaliyetler bazında sorumlu birim, kaynaklar ve hedefin yerine getirilme zamanı gibi bilgilere yer verilmesi öngörülmüştür. Ancak bu uygulamada harcama birimlerinin, stratejik plandan kopuk dokümante çalışması yapmış olmasının ötesine geçilememiştir.

Sorumlu birimlerin belirlenmesi açısından 2006 yılı uygulaması ile benzerlik gösterse de yeni rehberde, hedef kartlarının oluşturulmasının öngörülmesi, harcama birimlerinin sürece daha aktif katılımını sağlayacağı gibi taslak hedef kartlarının strateji geliştirme kurulunun onayından geçecek olması, idare stratejik planında bütünselliğin sağlanmasına yardımcı olacak bir uygulama olarak değerlendirilebilir. Bununla birlikte bu uygulama, idare ve birim performans programlarını uyumunu zorunlu kılmaktadır. İlgili idarelerden herhangi birinin performansı, bir diğerini ya da ötekileri etkileyebilecek, böylelikle işbirlikleri kaçınılmaz hale gelecektir. Hiçbir idare sürecin dışında kalmamış olacak, yıl sonunda faaliyet raporları birlikte hazırlanacak ve her idare planlama süreci ve plan uygulamasının bir parçası olarak faaliyetlerini sürdürecektir.

\title{
4.2. Koordine Edici İdarelerde Değişim
}

Anayasada yapılan değişikliklere uyum sağlanması amacıyla, bazı kanun ve kanun hükmünde kararnamelerde değişiklik yapmak üzere, 2018 yılında 703 sayılı KHK ${ }^{1}$ yayınlanmıştır. 703 sayılı KHK'nın 213. maddesine istinaden 5018 sayılı Kanunun madde hükümlerinde bazı değişiklikler gerçekleştirilmiştir. Bu değişiklikler çerçevesinde, mali yönetim sisteminin koordine edilmesine ilişkin olarak, genel olarak daha önce DPT (Kalkınma Bakanlığı) ve/veya Maliye Bakanlığına verilen görev ve yetkiler Cumhurbaşkanlığına verilmiştir. Bu çerçevede 5018 sayılı Kanunun "stratejik planlama ve performans esaslı bütçeleme" başlıklı 9. maddesine göre:

\begin{abstract}
"kamu idareleri geleceğe ilişskin misyon ve vizyonlarını oluşturmak, stratejik amaçlar ve ölçülebilir hedefler saptamak, performansların önceden belirlenmiş olan göstergeler doğrultusunda ölçmek ve bu sürecin izleme ve değerlendirmesini yapmak amacıyla katılımcı yöntemlerle hazırlayacakları stratejik planlarını, kalkınma planları, Cumhurbaşkanlığı tarafindan belirlenen politikalar, programlar, ilgili mevzuat ve benimsedikleri temel ilkelere dayandırmak zorundadır. Stratejik plan hazırlamakla yükümlü olacak kamu idarelerinin ve stratejik planlama sürecine ilişkin takvimin tespitine, stratejik planların politikalar, kalkınma planı ve programlarla ilişkilendirilmesine yönelik usul ve esaslar Cumhurbaşkanliğı tarafindan",
\end{abstract}

belirlenecektir. $\mathrm{Bu}$ düzenlemeler Cumhurbaşkanlığı hükümet sistemine uygun düzenlemelerdir. Cumhurbaşkanlığı 5018 sayılı Kanunda kendisine verilen bu görev ve yetkileri, "Strateji ve Bütçe Başkanlı̆̆l" aracılığıyla yerine getirecektir. Hazine ve Maliye Bakanlığı sürece destek verecektir. Bununla birlikte stratejik planlamaya ilişkin usul ve esaslar ile rehber ve standartlar da bundan sonra Cumhurbaşkanlığı Strateji ve Bütçe Başkanlığı tarafından yayınlanacaktır. Nitekim Başkanlık, 2018 yılında Belediyeler İçin Stratejik Planlama Rehberini hazırlamış ve yayınlamıştır. Bununla birlikte, daha önce, yine 2018 yılında Kalkınma Bakanlığı tarafından hazırlanıp yayınlanan "Kamu İdareleri İçin Stratejik Planlama Kılavuzu 3. Sürüm", Stratejik Planlama İçin Analiz ve Yöntemler Rehberi, Kamu İdarelerinde Stratejik Planlamaya İlişkin Usul ve Esaslar Hakkında Yönetmelik halen yürürlüktedir.

Kalkınma planı, orta vadeli program ve mali yönetime ilişkin politika dokümanları Strateji ve Bütçe Başkanlığı tarafından hazırlanmaktadır. Kalkınma planı yanı sıra, diğer bir üst politika belgesi olarak anılan "Cumhurbaşkanlığı tarafindan belirlenen politikalar ve programlar"'dan Cumhurbaşkanlığı bünyesinden tesis edilmiş politika kurulları ve bakanlıkların önerilerinden "Cumhurbaşkanı tarafindan kabul edilenler" olduğu

1 Anayasada Yapılan Değişikliklere Uyum Sağlanması Amacıyla Bazı Kanun ve Kanun Hükmünde Kararnamelerde Değişiklik Yapılması Hakkında Kanun Hükmünde Kararname (09.07.2018 tarih ve 30473 sayılı (3. Mükerrer) Resmi Gazete). 
anlaşılmaktadır. Buna göre Cumhurbaşkanlığı bünyesinde dokuz adet politika kurulu ${ }^{2}$ oluşturulmuştur. ${ }^{3}$ Çalışmanın özellikle kapsamını ilgilendiren kurul, "Yerel Yönetim Politikaları Kurulu"'dur". Belediyelerin stratejik planlarına dayanak oluşturması açısından her bir politika kurulunun önerisiyle oluşturulacak politika belgeleri önem arz etmekle birlikte, Yerel Yönetim Politikaları Kurulu görev ve yetki alanı itibariyle öne çıkmaktadır.

Yerel yönetimlerle ilgili olarak daha önce İçişleri Bakanlığı bünyesinde bulunan Mahalli İdareler Genel Müdürlüğü hizmet birimi olarak Yerel Yönetimler Genel Müdürlüğü adıyla ve vesayete ilişkin yetkiler İçişleri Bakanlığında bırakılarak Çevre ve Şehircilik Bakanlığı bünyesine alınmıştır. Buna göre yerel yönetimlere yönelik olarak "görevden uzaklaştırma, soruşturma izni verilmesi, teftiş, denetim, inceleme, ön inceleme gibi hususlar ile onay ve izin gibi idari vesayetten kaynaklanan ve idari vesayetin doğal sonucu olan tüm yetkiler", İçişleri Bakanlığı tarafından kullanılmaya devam edilecek, bunlar haricinde ve 1 Nolu Cumhurbaşkanlığı Kararnamesinde yer alan ve Çevre ve Şehircilik Bakanlığının görevleri arasında yer verilen "mahalli idareleri ve bunların merkezi idare ile olan alaka ve münasebetlerini düzenleme fonksiyonu" dışında bir fonksiyon üstlenmesi mümkün olmayacaktır (Turan, 2018:66). Bu çerçevede daha önce yerel yönetimlerde plan - politika ilişkisini koordine etmek üzere İçişleri Bakanlığına verilen yetkiler, vesayet yetkisi İçişleri Bakanlığına kalmak üzere, Çevre ve Şehircilik Bakanlığına verilmiştir. Buna göre, 29 Kasım 2018 tarihinde kabul edilen değişiklikle 5018 sayılı Kanunun 10. Maddesinde:

"bakanlar, Cumhurbaşkanı tarafindan belirlenen politikaların uygulanması ile bakanlıkların ve bakanlıklara bağll, ilgili ve ilişkili kuruluşların stratejik planları ile bütçelerinin kalkınma planlarına, yillık programlara uygun olarak hazırlanması ve uygulanmasından, bu çerçevede diğer bakanlıklarla koordinasyon ve işbirliğini sağlamaktan sorumludur. Bu sorumluluk, yerel yönetimler açısından Çevre ve Şehircilik Bakanlığına verilmiştir. Çevre ve Şehircilik Bakanlığı bu sorumluluğunu Yerel Yönetimler Genel Müdürlüğ̈̈ aracıllğılyla yerine getirecektir ",.

Daha önceki dönemlerde DPT ile başlayıp, Maliye ve Kalkınma Bakanlıkları arasında organize edilen bu yetki ve sorumlulukların, Çevre ve Şehircilik Bakanlı̆̆ı'na bırakılması ciddi bir idari kapasite ihtiyacını doğuracaktır. Buna ilişkin personel ve teknik alt yapının geliştirilmesine yönelik projeler gündemdedir.

2 Bu kurullar; “i) Bilim, Teknoloji ve Yenilik Politikaları Kurulu, ii) Eğitim ve Öğretim Politikaları Kurulu, iii) Ekonomi Politikaları Kurulu, iv) Güvenlik ve Dış Politikalar Kurulu, v) Hukuk Politikası Kurulu, vi) Kültür ve Sanat Politikaları Kurulu, vii) Sağlık ve Gıda Politikaları Kurulu, viii) Sosyal Politikalar Kurulu, ix) Yerel Yönetim Politikaları Kurulu" (1 Nolu Cumhurbaşkanlığı Kararnamesi, md. 20).

3 Politika kurullarının genel görev ve yetkileri şunlardır; “i) Cumhurbaşkanınca alınacak kararlar ve oluşturulacak politikalarla ilgili öneriler geliştirmek, ii) Geliştirilen politika ve strateji önerilerinden Cumhurbaşkanınca uygun görülenler hakkında gerekli çalışmaları yapmak, iii) Küresel rekabetin getirdiği ani değişimlere karşı strateji ve politika önerileri geliştirmek, iv) Görev alanlarına giren konularda kamu kurum ve kuruluşlarına görüş vermek, v) Görev alanlarına giren konularda Bakanlıklar, kurum ve kuruluşlar, sivil toplum ve sektör temsilcileri, alanında uzman kişiler ve ilgili diğer ilgililerin görüşünü alarak uygulanan politikaları ve gelişmeleri izlemek, yapılan çalışmalarla ilgili Cumhurbaşkanına rapor sunmak, vi) Cumhurbaşkanı programına uygunluk açısından, bakanlık ile kurum ve kuruluşların uygulamalarını izlemek ve Cumhurbaşkanına rapor sunmak, vii) Bakanlıklar, kurum ve kuruluşlar, sivil toplum ve sektör temsilcileri, alanında uzman kişiler ve ilgili diğer ilgililerin davet edilmesi suretiyle genişletilmiş kurul toplantılart yapmak, viii) Görev alanına giren konularda, talep, ihtiyaç ve etki analizi yapmak ve/veya yaptırtmak, ix) Cumhurbaşkanına verilen diğer görevleri yapmak".

4 Yerel yönetim politikaları kurulunun görev ve yetkileri şunlardır; "i) Kentleşme ve yerel yönetim alanında politika ve strateji önerileri geliştirmek, ii) Türkiye'nin toplumsal, ekonomik ve siyasal gerçekliklerine uygun olarak yerel yönetim politikalarına ilişkin strateji önerileri sunmak, iii) Göç ve iskân konularında politika önerileri geliştirmek, iv) Çevre, orman, su ve benzeri alanlarda koruyucu ve geliştirici politika önerileri geliştirmek, v) Türkiye'nin kültürel mirasından beslenerek kentleşme politikası önerileri geliştirmek, vi) Akıllı şehircilikle ilgili araştırmalar yaparak strateji önerilerinden bulunmak, vii) Boğaziçi imar uygulamaları programları gereği kamu yatırımlarının planlanmasına ilişkin çalışmalar yapmak, viii) Etkin bir çevre yönetiminin sağlanması için politika ve strateji önerileri geliştirmek" (1 Nolu Cumhurbaşkanlığı Kararnamesi, md. 31).

57153 sayılı Çevre Kanunu ve Bazı Kanunlarda Değişiklik Yapılmasına Dair Kanun, (10.12.2018 tarih ve 30621 sayılı Resmi Gazete).

6 Yeni yönetim sistemi ile “Íçişleri Bakanlığı” bünyesinde yer alan “Mahalli İdareler Genel Müdürlügü̈”nün adı "Yerel Yönetimler Genel Müdürlüğü” olarak değiştirilmiş ve “Çevre ve Şehircilik Bakanlı̆̆ı” "na bağlanmıştır. 


\section{SONUÇ}

Stratejik planlama rehberinin yeni sürümü uygulamaya konulmuştur. Plan, yönetim ve kurumun sahiplenmesine dayanmaktadır. Daha önceden sadece "ne yapılacağına" ilişkin oluşturulan bir stratejik plan yerine; "neyi, neden yapacağını açıklayan" bir stratejik plan yaklaşımı ortaya çıkmıștır. Sorumlular ve sorumluluklar daha açıklayıcı ve kapsayıcıdır. İzleme ve değerlendirme süreçleri ne yapıldığı kadar nelerin yapılamadığı ve bunun nedenlerini de açıklamaya yöneliktir. Sürekli bir gözlem ve hedeflere ulaşma hususu değerlendirmeye alınmaktadır. Politika - plan ve bütçe ilişkisi, daha açık bir şekilde ele alınmaktadır. Hesap verme araçları başta iç denetim faaliyetleri olmak üzere, Sayıştay performans raporlarının belediye meclislerinin gündemine girmesi kayda değer bir durumdur.

Belediyeler için Stratejik Plan Hazırlama Rehberi açısından değerlendirme yapıldığında, rehberin 2006 yılında hazırlanan Kamu İdareleri İçin Stratejik Plan Kılavuzuna kıyasla önemli farklılıklar ve yenilikler getirdiği ortaya çıkmıştır. Buna göre, stratejik planlama konusunda, belediyeler özelinde ayrı bir rehber hazırlanması, kamu idareleri için genel olarak hazırlanan rehber ve kılavuzlara uyum sağlama konusunda ciddi zorluklar yaşayan belediyeler açısından önemli bir adımdır. Öte yandan söz konusu rehber, önceki uygulamalardan farklı olarak stratejik planın sorumluluk ve hesap verme alanlarında yeni bir bakış açısı getirmiştir. Buna göre, rehberin getirdiği en önemli yaklaşım, katılımcılığa yaptığı vurgudur.

İdare içi planlama kademesinde, stratejik plan ekibince hazırlanan çalışmaların her birinin, strateji geliştirme kurulu onayından geçecek olması, kurul üyeleri göz önüne alındığında, operasyonel düzeydeki faaliyet ve proje hedefleri ile idare düzeyindeki stratejilerin uyumlaştırılması, bütünleştirilmesi, tarafların birbirini anlaması açısından önemli bir yeniliktir. Rehberin getirdiği diğer önemli bir yaklaşım, stratejik planlama sürecinin üç ana kademesinden biri olan durum analizi ile diğer kademeler arasında neden-sonuç ilişkisini kurması, durum analizini salt niceliksel verilerin paylaşıldığı bir alan olmaktan çıkarmasıdır. Buna göre stratejik planlama sürecinin iki ana kademesinden biri amaç-hedef ve performans göstergelerinin belirlendiği aşama, ikincisi ise izleme ve değerlendirmedir. Yeni rehber bu üç aşama arasında döngüsel bir bağ kurarak, stratejik planların, stratejinin özüne aykırı bir biçimde statik bir yapıdan kurtulup dinamik, değişen koşullara önemli yapısal, yasal değişimlere duyarlı bir hale getirmektedir.

Rehberin getirdiği bir diğer yaklaşım ise risk değerlendirme ve yönetimi sürecini stratejik planlama sürecinin temeli haline getirmesidir. Esasen idareler iç kontrol sistemine ilişkin çalışmalarının bir parçası olarak risk konusunda çalışmaktadırlar. Ancak riskin hesaba katılarak, stratejik planlama sürecinin bir parçası olan yaklaşım, üst yönetimin 5018 sayılı Kanunda öngörülen yönetim sorumluluğunu tam olarak karşılamaktadır. Bununla birlikte iç kontrol sistemi, kurumsal yönetim, stratejik planlama gibi mali yönetimin ayrılmaz unsurlarının bütünleştirilmesine de imkân vermektedir.

Son olarak rehberin getirdiği diğer bir önemli yaklaşım ise hedef kartlarının oluşturulacak olmasıdır. Bu hedef kartlarının dikkat çeken yanı performans göstergelerinin mevcut değeri ile gösterge hedeflerini karşılaştırması, göstergelerin hedefe etkisini, sorumlu birimleri, riskleri ve maliyetleri içerecek şekilde tasarlanmış olmasıdır. $\mathrm{Bu}$ yaklaşım, samimiyetle uygulanması durumunda, uzun yıllardır kamu kesiminde sonuç odaklı yaklaşımın hayata geçirilmesi anlamına gelmektedir. Çünkü bu sayede, izleme ve değerlendirme sistemlerinin kurulması ve fonksiyonel olarak işletilebilmesi mümkün olabilecektir. Henüz planlama aşamasında iken belediyeler üst politika belgeleri ile kendi faaliyetleri arasında ilişkiyi kuracak, belediye operasyonel düzeyleri, kendi faaliyetleri ile belediye amaçları arasındaki ilişkiyi gözetebilecektir.

Yeni yönetim sistemi çerçevesinde belediyeler için yeni aktörler açısından, bazı tespit ve önerilerde bulunulabilir:

- Illk olarak, Çevre ve Şehircilik Bakanlığı; Cumhurbaşkanı tarafından belirlenen politikaların uygulanması ile bakanlıkların ve bakanlıklara bağlı, ilgili ve ilişkili kuruluşların stratejik planları ile bütçelerinin kalkınma planlarına, yıllık programlara uygun olarak hazırlanması ve uygulanmasından, bu çerçevede diğer bakanlıklarla koordinasyon ve işbirliğini sağlamaktan sorumlu kılınmış ve bu sorumluluğunu Yerel Yönetimler Genel Müdürlüğü aracıllğgiyla yerine getirecektir (5018 say. Kanun, md.10). Ulusal ve yerel planlar arasında koordinasyon ve uyum sağlanması açısından benimsenen yaklaşıma işlevsellik kazandırılmalıdır. Ayrıca, işlevsellik kazandırmak için belediyelerin planlama yapma özerkliğini zedelemeyecek, teknik anlamda bir inceleme yapılmasını sağlayacak adımlar atılmalıdır.

- Íkinci olarak, belediye başkanları; belediyelerin stratejik planlarının ve bütçelerinin kalkınma planına, y1ll1k programlara, kurumun stratejik plan ve performans hedefleri ile hizmet gereklerine uygun olarak 
hazırlanması ve uygulanmasından, sorumlulukları altındaki kaynakların etkili, ekonomik ve verimli şekilde elde edilmesi ve kullanımını sağlamaktan, kayıp ve kötüye kullanımının önlenmesinden, malî yönetim ve kontrol sisteminin işleyişinin gözetilmesi, izlenmesi ve kanunlar ile Cumhurbaşkanlığ kararnamelerinde belirtilen görev ve sorumlulukların yerine getirilmesinden belediye meclislerine karşı sorumlu kılınmış ve bu sorumluluğunu harcama yetkilileri, malî hizmetler birimi ve iç denetçiler aracılığıyla yerine getirmektedir (5018 say. Kanun, md.11). Ancak stratejik plan sürecinin izlenmesi ve değerlendirilmesinin doğru şekilde gerçekleştirilmemesi sorun yaratmaktadır. Bu nedenle belediyelerde izleme ve değerlendirmeye ilişkin gerek kavramsal gerek teknik altyapının oluşturulması önemlidir. Bu sorununun çözümü için merkezi kurumların koordinatörlüğ̈̈nde ortak kullanılabilir bir yapı oluşturulabilir (Yılmaz ve Erkan, 2014:13). Yeni oluşturulan Strateji ve Bütçe Başkanlığı bünyesinde bu eksiklik giderilebilir.

- Üçüncü olarak, belediyeler tarafından hazırlanan idare faaliyet raporlarının birer örneği Sayıştay ve Çevre ve Şehircilik Bakanlığına gönderilir. Çevre ve Şehircilik Bakanlığı, bu raporları esas alarak kendi değerlendirmelerini de içeren yerel yönetimler genel faaliyet raporunu hazırlar ve kamuoyuna açıklar. Raporun birer örneği Sayıştay’a ve Cumhurbaşkanlığına gönderilir (5018 say. Kanun, md.41) ${ }^{7}$. Yeni yönetim sistemi ile Maliye Bakanlığı'na ait olan bu yetki Cumhurbaşkanına verilmiştir.

Anlaşılacağ üzere, stratejik plan hazırlama sürecinde yeni bir aktör olan Cumhurbaşkanlığı Strateji ve Bütçe Başkanlığı'nın rolü ve işleyişi oldukça önemlidir. Akman E. (2019:50) tarafından yapılan çalışmada Cumhurbaşkanı, ofisler ve politika kurulları arasındaki ilişki bir çarkın dişlilerine benzetilmiştir. Aynı benzetme stratejik plan hazırlama süreci için de yapılabilir. Ancak bu kez ana dişli, Cumhurbaşkanı yerine Strateji ve Bütçe Başkanlığı olarak düşünülebilir. Diğer dişliler ise Çevre ve Şehircilik Bakanlığı (Yerel Yönetimler Genel Müdürlüğü) ve belediyeler olmalıdır. Nasıl bir dişli sisteminde dişli çapı, diş yapısı ve dönüş hızı farklı olmasına rağmen birlikte çalıştıklarında bir bütünlük arz ediyor ve anlamlı sonuçlar çıkıyorsa bu sistemde de durum benzer olmalıdır. Bu nedenle üç aktör arasındaki uyum, oldukça önemlidir. Ancak 5018 sayılı Kanuna göre, belediyelerin stratejik planlarının ulusal planlar ile koordinasyon görevi Çevre ve Şehircilik Bakanlığı'na aittir. Ancak planlar arasındaki uyumu nasıl kontrol edeceği ile ilgili açık bir husus bulunmamaktadır. Bu görevin Strateji ve Bütçe Başkanlığı ile koordineli yürütülmesi sorunun çözümüne katkı sağlayacaktır.

Ulusal planlar ile belediyeler tarafindan hazırlanan planlar arasında bütünlük olması, oldukça önemli bir husustur. Bu husus ulusal planların başarılı olabilmesinin de temel koşuludur. Ancak yeni yönetim sistemi ile getirilen değişiklik ile de ulusal ve yerel planlar arasındaki koordinasyonu sağlayıcı gerekli adımlar atılmamıştır. Hala bunun için gerekli yasal düzenleme yapılmamış olması, önemli bir eksiklik olarak karşımıza çıkmaktadır. Ancak, Strateji ve Bütçe Başkanlığı kurulması ve başkanlık bünyesinde bu konuyla ilgilenen özel bir birimin olması (Plan ve Programlar Genel Müdürlüğü) önemli bir firsat olarak karşımıza çıkmaktadır. Etkin bir stratejik planlama süreci yürütülebilmesi yani dişlilerin doğru hareket edebilmesi için gerekli adımlar, yerel yönetimler için de atılmalıdır.

7 Sayıştay sadece yerel yönetimler genel faaliyet raporunu inceler ve görüşlerini Türkiye Büyük Millet Meclisine sunar. "Türkiye Büyük Millet Meclisi bu raporlar ve değerlendirmeler çerçevesinde, kamu kaynağının elde edilmesi ve kullanılmasına ilişkin olarak kamu idarelerinin yönetim ve hesap verme sorumluluklarını görüşür. Bu görüşmelere üst yönetici veya görevlendireceği yardımcısının ilgili bakanla birlikte katılması zorunludur. İdare faaliyet raporu, ilgili idare hakkındaki genel bilgilerle birlikte; kullanılan kaynaklarl, bütçe hedef ve gerçekleşmeleri ile meydana gelen sapmaların nedenlerini, varlık ve yükümlülükleri ile yardım yapılan birlik, kurum ve kuruluşların faaliyetlerine ilişkin bilgileri de kapsayan malî bilgileri; stratejik plan ve performans programı uyarınca yürütülen faaliyetleri ve performans bilgilerini içerecek şekilde düzenlenir. Bu raporlarda yer alacak hususlar, raporların hazırlanması, ilgili idarelere verilmesi, kamuoyuna açıklanması ve bu işlemlere ilişkin süreler ile diğer usûl ve esaslar Sayıştayın görüşü alınarak Cumhurbaşkanı tarafindan çıkarılacak yönetmelikle belirlenir" (5018 say. Kanun, md.41). 


\section{KAYNAKÇA}

ACAR, İbrahim Attila ve ŞAHİN, Elif Ayşe (2009), "Plan - Bütçe İlişkisi Açısından İç Denetim”, Maliye Dergisi, S.156, ss.83-103.

AKDOĞAN, Argun (2007), "Stratejik Planlama Yerine Planlama Stratejisi: Belediyelerin Stratejik Planlarının Karşılaştırılmalı Incelenmesi", TMMOB Mahalli İdarelerde Dönüşüm Sempozyumu Bildiriler Kitabı, TMMOB Yayını, Ankara, ss.53-58.

AKMAN, Çiğdem (2019), “Cumhurbaşkanlı̆̆ı Hükümet Sisteminde Politika Kurulları: Sosyal Politikalar Kurulu Üzerinden Bir Değerlendirme”, Route Educational And Social Science Journal, S.6(3), ss.659676.

AKMAN, Çiğdem ve ÖZASLAN, Ahmet (2018), "Türkiye'de Stratejik Planlama: Büyükşehir Belediyelerinin Stratejik Planları Ne Söylüyor?”, Avrasya Uluslararası Araştırmalar Dergisi, S.6(14), ss.55-90.

AKMAN, Elvettin (2019), “Cumhurbaşkanlı̆̆ı Hükümet Sisteminde Kamu Politikası Aktörleri”, Paradoks Ekonomi Sosyoloji ve Politika Dergisi, S.15(1), ss.35-54.

DINAPOLI, P. Thomas (2003), Local Government Management Guide Strategic Planning, Office of The New York State Comptroller Publisher, New York.

DİNÇER, Ömer ve YILMAZ, Cevdet (2003), “Değişimin Yönetimi İçin Yönetimde Değişim”, Kamu Yönetiminde Yeniden Yapılanma: 1, T.C. Başbakanlık Yayınları, Ankara, http://www.sp.gov.tr/upload/xSpKutuphane/files/ewRtI+Degisimin_Yonetimi_icin_Yonetimde_Degisim _2003_.pdf (Erişim Tarihi: 20.03.2019).

DPT - DEVLET PLANLAMA TEŞKİLATI (2006), Kamu İdareleri İçin Stratejik Planlama Kılavuzu, DPT Yayını, Ankara, 2. Sürüm, http://www.yapi.hacettepe.edu.tr/dosyalar/stratejik_planlama_klavuzu.pdf (Erişim Tarihi: 20.03.2019).

ERKAN, Volkan (2008), Kamu Kuruluşlarında Stratejik Planlama Türkiye Uygulaması ve Kuruluşlarda Başarıyı Etkileyen Faktörler, DPT Yayını, Ankara.

GOODMAN, Dough ve CLYNCH, Edward J. (2004), "Budgetary Decision Making by Executive and Legislative Budget Analysits: The Impact of Political Cues and Analytical Information”, Public Budgeting And Finance, Fall, ss.20-37.

GÖZLÜKAYA, Türkay (2007), "Yerel Yönetimler ve Stratejik Planlama: Modeller ve Uygulama Örnekleri”, Yüksek Lisans Tezi, Pamukkale Üniversitesi Sosyal Bilimler Enstitüsü, Denizli.

GÜNGÖR, Burak (2011), "Yerel Yönetimlerde Stratejik Yönetim Yaklaşımı: Ankara ve Bursa Büyükşehir Belediyesinde Uygulanan Yöntemlerin Karşılaştırılması”, Yüksek Lisans Tezi, Selçuk Üniversitesi Sosyal Bilimler Enstitüsü, Konya.

HAŞAR, Çetin (2008), "Samsun Il Gelişim Stratejisi Deneyimi", Planlamadan Uygulamaya Konulu 3. Bölgesel Kalkınma ve Yönetişim Sempozyumu Bildiriler Kitabı, Mersin, ss.293-305.

HOU, Yilin ve MA, Jun (2006), “Chapter 5: Annual Budgeting and Long Range Planning: Is There a Fit?Lessons from Three Case Studies", Public Financial Management: Public Administration and Public Policy (Ed. Howard A. Frank), CRC Press, 1st printing, ss.117-148.

KALKINMA BAKANLIĞI (2006), "Dokuzuncu Kalkınma Planı Kamu Harcamaları ve Kontrol Sisteminin İyileştirilmesi”, Kamu İhaleleri Özel İhtisas Komisyonu Raporu, Kalkınma Bakanlığı Yayını, Ankara.

KALKINMA BAKANLIĞI (2018), Kamu İdareleri İçin Stratejik Planlama Kılavuzu, 3. Sürüm, http://www.sp.gov.tr/upload/xSpKutuphane/files/VrllQ+Kamu_Idareleri_Icin_Stratejik_Planlama_Kilavu zu.pdf (Erişim Tarihi: 20.03.2019).

ÖZ, Ersan ve KAPLAN, Ersin (2005), “Türk Mali Sisteminin Yeniden Yapılandırllması”, Türk İdare Dergisi, S.446, ss.243-261.

ÖZGÜR, Hüseyin (2004), “Kamu Örgütlerinde Stratejik Yönetim”, Çağdaş Kamu Yönetimi II (Ed. Muhittin Acar ve Hüseyin Özgür), Nobel Yayınları, Ankara, ss.207-252. 
SONGÜR, Neşe (2008), "Stratejik Plan Hazırlamakla Yükümlü Belediyelerin Deneyimleri Üzerine Bir Araştırma", 1. Ulusal Yerel Yönetimler Sempozyumu Bildiriler Kitabı, Sakarya, ss.71-83.

ŞAHIN İPEK, Elif Ayşe (2014), “Türkiye'de Mahalli İdare Bütçeleri ve Sorunları”, Mali Yerinden Yönetim: Teori, Kavramsal Açıklamalar ve Türkiye'ye İlişkin Değerlendirmeler (Ed. Mustafa Sakal, Ahmet Kesik ve Tekin Akdemir), Nobel Yayınlar1, Ankara, ss.332-354.

ŞAHIN İPEK, Elif Ayşe (2013), Kamu Kesiminde Performans Yönetim Aracı Olarak Performans Esaslı Bütçeleme Sistemi: Büyükşehir Belediyeleri Örneği, TBB Yayını, Ankara.

T. C. CUMHURBAŞKANLIĞI (2018), Strateji ve Bütçe Başkanlığı Teşkilatı Hakkında Cumhurbaşkanlığı Kararnamesi (CBK-13), (24.07.2018 tarih ve 30488 sayıl1 Resmi Gazete).

TBMM (2018), Yeni Sisteme Göre Yasama El Kitabı, TBMM Kanunlar ve Kararlar Başkanlığı Yayını, Ankara, https://www.tbmm.gov.tr/yayinlar/Yasama_El\%20Kitabi.pdf (Erişim Tarihi: 11.03.2019).

THE WORLD BANK (1998), Public Expenditure Management Handbook, 1st printing, Washington, D.C.

TURAN, A.Menaf, (2018), “Türkiye’nin Yeni Yönetim Düzeni: Cumhurbaşkanlı̆̆ı Hükümet Sistemi”, Sosyal Bilimler Araştırma Dergisi, S.7(3), ss.42-91.

YILMAZ, H. Hakan ve ERKAN, Volkan (2014), "Belediyelerde Stratejik Planlama: Yaşanan Deneyimin Belirleyiciliğinde Önümüzdeki Döneme İlişkin Öneriler”, Türkiye Belediyeler Birliği Dergisi, S.789, ss.58-69. 